Document downloaded from:

http://hdl.handle.net/10251/138475

This paper must be cited as:

Palau-Salvador, G.; De Luis, A.; Juan Pérez, J.; Sanchis Ibor, C. (09-2). Greening the post crisis. Collectivity in private and public community gardens in València (Spain). Cities. 92:292-302. https://doi.org/10.1016/j.cities.2019.04.005

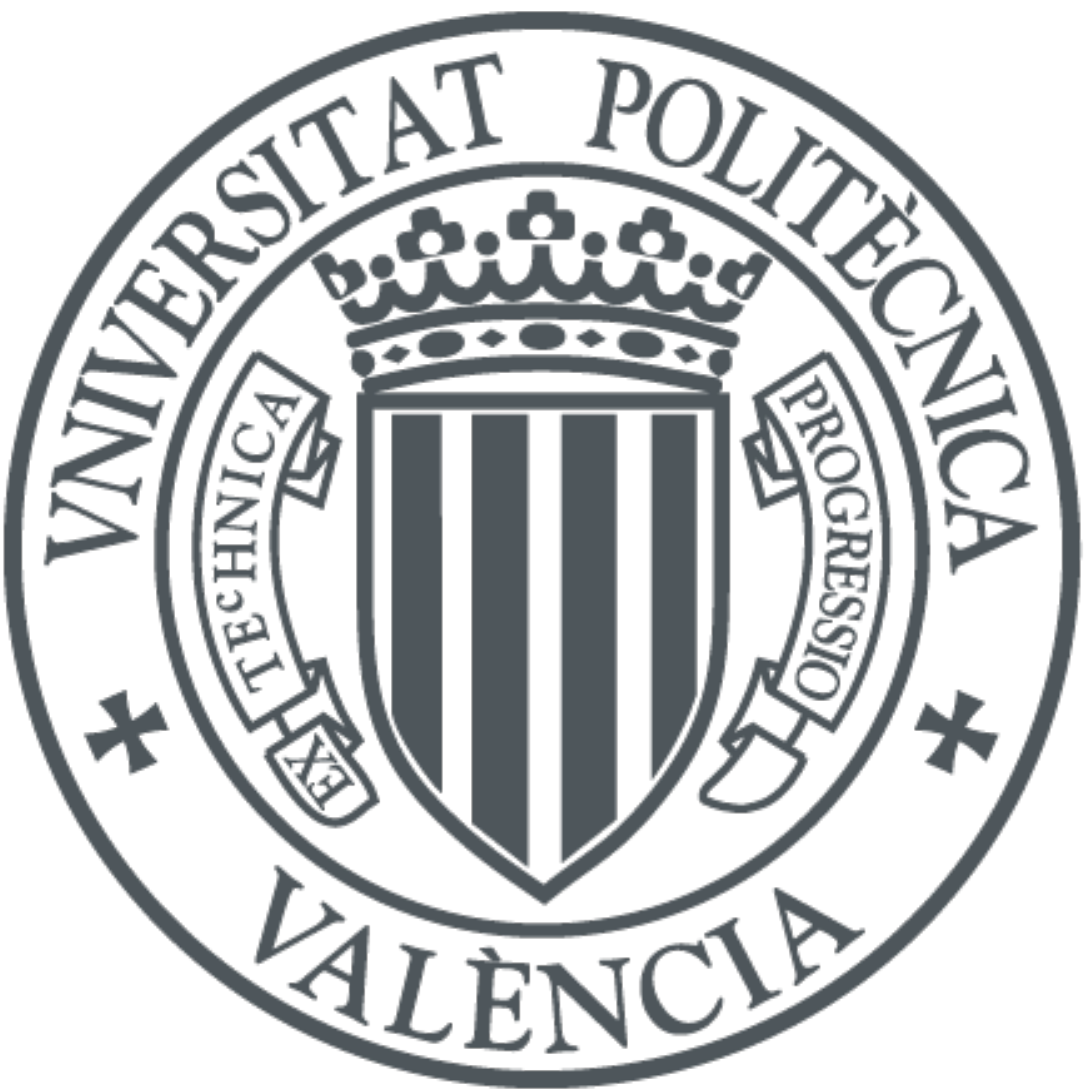

The final publication is available at

https://doi.org/10.1016/j.cities.2019.04.005

Copyright Elsevier

Additional Information 


\title{
Greening the post crisis. Collectivity in private and public community gardens in València (Spain)
}

\begin{abstract}
Unlike other Western European countries, community gardens have appeared very recently in Spain, and they have rapidly increased during the last decade. Community gardens have adopted different forms -rental, municipal and associative- with contrasted managerial practices. This paper analyzes collectivity of community gardens in València (Spain), including private initiatives, through semi-structured interviews conducted in different gardens of the València Metropolitan Area. Results show how the financial crisis has acted as a catalyst for urban greening latent demands, causing the expansion of community gardens. Despite the different structure, practices and rules of private and public gardens, all of them share aims and actions related to urban greening, food sovereignty, organic farming and community building, and show similar benefits to those observed in other countries. Moreover, the rental gardens allow farmers to expand their services and to engage directly with consumers.
\end{abstract}

Key words

Urban agriculture; community gardens; food sovereignty; collectivity; urban greening; entrepreneurship.

\section{Introduction}

Urban agriculture has emerged simultaneously in many cities of the world, colonizing diverse interstices of the urban scene and adopting different forms and social patterns (Mougeot, 2000, 2005; Viljoen, 2005; McClintock and Simpson, 2014). It is part of the social response to the hazards and insecurities induced by modernization itself (Beck, 1992; Giddens and Pierson 1998) and introduced by the generalization of the urban culture. Some authors have understood this phenomenon as a countermovement at the local level aiming at restoring part of the metabolic rift opened between humans and nature by urbanization (McClintock, 2010). Recent community gardens have proliferated at the confluence of three discourses: the urban greening strategies addressed to improve the social conditions in urban areas affected by degradation, renewal or gentrification; the so-called people-plant interactions through individual gardening practice; and the environmental activism (Pudup, 2008). These three discourses shape a critical approach to the current forms of urbanization through the implementation of new ecologically sound and fair forms of dwelling the cities (Hodkinson, 2012), creating opportunities of reconnection between food production, ethics and consumption, and experimenting with the regeneration of some urban commons (Tornaghi, 2014).

In the recent years, as part of what Jackson (2009) call the Keynesian "Green New Deal", authorities have shown an increasing support to these actions, which is crystalizing globally in local policies, such as Food Policy Councils in the United States (Patel, 2009), United Kingdom (Moragues-Faus et al., 2017b) or African cities (Morgan, 2009). All these initiatives were added in International Agreements such as the Milan Urban Food Policy Pact (2015), encouraging cities 
to identify, map and evaluate local projects and civil society food movements. The public support for urban agriculture is based on a wide acknowledgement of the multifunctional value of these areas. Beyond food production and other related health benefits (Kingsley et al., 2009; Teig et al., 2009; Hale et al., 2011; Corrigan, 2011), community gardens have evinced a significant capability to build both social capital and connectedness (Glover, 2004; Kingsley and Thowsend, 2006; Nette, 2014), to achieve relevant levels of collective empowerment in different geographical contexts, and to promote social inclusion and facilitate inter-racial and immigrant integration (Nemore, 1998; Armstrong, 2000; Shinew et al, 2004, Agustina and Beilin, 2012). Their contribution to ecosystem services (Barthel et al., 2010; Cabral et al, 2017) is determinant in constructing local strategies of sustainability (Holland, 2004; Aubry et al., 2012). Finally, urban agriculture is considered a useful tool in enhancing the nutrition of urban dwellers in the global South (Maxwell, 1998; Madaleno, 2000; Zezza and Tasciotti, 2010), for the low income collectives of the unequally developed North, or even in the food deserts generated in cardependent cities (Wang et al, 2014).

Collectivity arises in urban agriculture among all these benefits and values, as a broad concept, which gathers: i) collective learning processes, ii) collective resources management, and iii) common political attitudes. First, the communities of practice notion (Wenger, 1998, 2000) highlights the importance of learning processes in the construction of social capital and community building. Communities of practice represent a shared history of learning, which require a mutual engagement of people in a joint enterprise about a particular endeavor, such as collective gardening, sharing rules, infrastructures, techniques and jargon, in order to progress individually and collectively (Bendt et al., 2018). Second, Exner and Schützenberger (2018) have defined a functional concept of collectivity related the spatial configuration of individual and communal areas within the garden, and the organization of activities. This allows for the quantification of collectivity through the analysis of five material and immaterial components of common-pool resources management: resources system, infrastructure, resource units, work and social time (Rogge and Theesfeld, 2018). Third, the "politics of collectivity" (Moragues-Faus, 2017a) contributes to explaining how these groups formulate and institutionalize their political goals. This idea of collectivity, nested in post-democratic spaces (Swyngedouw, 2011), enforces the concept of public as the realm of people claiming on urban spaces, and it gathers principles like, collective responsibility, participation, collaboration and also the care taken by among participants (Nettle, 2014; Moragues-Faus, 2017a). This collectivity dimension, together with specific political goals, aims at pursuing neighborhood revitalization and community building (Smith and Kurtz, 2003).

Research on community gardens and collectivity is still geographically limited (Guitart et al., 2012). The majority of the consulted research works refer to English speaking countries. Few (but very recent) works have been developed in the Mediterranean area (Slavuj et al., 2016; Filkobski et al., 2016; Seguí et al., 2017; Pirro and Anguelovski, 2017; Simon-Rojo et al., 2018). For this reason, in this paper we focus on Spain, where community gardens have appeared very recently, although opportunistic or informal individual gardens were frequent - particularly during (and after) the rural exodus of the $20^{\text {th }}$ century. The arrival of deprived rural population in the cities and the development of marginal self-constructed suburbs took place in parallel with the spontaneous occupation of vacant lands for gardening. These class-produced natures (Domene and Saurí, 2006; Faus, 2012), perceived as vulgar and undesirable landscapes by part of the citizens, considerably decreased in number in the 1990s, being replaced by new private or public infrastructures, or housing developments. The decline of this formula coincides in time and space with the pioneer development of community gardens. Following the models of the 
Anglo-Saxon and North-European countries, the first Spaniard community gardens appeared almost simultaneously in Barcelona, Madrid and Sevilla in the 1980 decade, but the number of gardens slowly increased across the country up to 21 in 2007 (Ballesteros, 2014).

By the beginning of the $21^{\text {st }}$ century, Spain was immersed in a real-estate bubble. The urban sprawl accelerated, expanding cities and launching new public infrastructures. In 2008 the speculative bubble burst. Consequently, the work market collapsed with unemployment rising from $8 \%$ to $26 \%$, urban expansion stopped and numerous land developments were abandoned. Then, urban agriculture emerged as a strategy for unemployed and low income citizens to produce part of their own food, but mainly for middle class urban dwellers searching for a reconnection with food production and nature. Numerous potential locations for urban agriculture appeared in the lands abandoned by ruined urban developers (Seguí et al., 2017)

Popular contestation to the financial crisis forged a discourse that intertwined social and environmental demands, partially aligned with the principles of the food sovereignty global movement and the organic farming defenders. Indeed, in May 2011, a post-crisis national protest movement called "15-M" planted symbolic small gardens in the encampments set up at the main squares of Madrid and Barcelona. This movement catalyzed citizen's participation and mobilization. The occupation of urban vacant lands to develop collective gardens became part of a wider strategy of urban renewal and neighborhood empowerment, which was materialized in numerous Spanish cities as a crossroad between food sovereignty and participative urbanism opposed to neo-liberal models (Fernández and Morán, 2015; Pirro and Anguelovski, 2017; Simon-Rojo et al., 2018).

The typology of the community gardens in Spain is varied, although two main styles have arisen: movement-related community gardens and individually-assigned allotments (Seguí et al., 2017). The first type is related with social movements where it is cultivated a common garden among the participants and it is normally accompanied with political activities and social engagement. The second one is normally promoted by local authorities and a small individual plot is assigned to each user. This community garden type is more focused on health, open-air leisure activities or social inclusion than the movement-related one.

The case of the València Metropolitan Area (VMA) shows a more varied pattern. First, because all the gardens promoted by Non-Profit Organizations or social and political movements offer individual plots for the users. Second, because private initiatives (farmers or also other entrepreneurs) have created numerous collective rental gardens for urban dwellers. For these reasons, and according to the managerial structure of the gardens, we have classified them in 3 categories: i) municipal gardens, managed by city councils and settled on public lands, with social or leisure objectives; ii) associative gardens, managed by NGOs with different aims, which were also identified in subcategories (agro-environmental, social, educational and political); iii) rental gardens, managed by farmers or entrepreneurs on private lands (Figure 1).

The aim of this research, based on the case of the VMA, is: i) to analyze the singularity of community gardens expansion in the VMA and its connection to recent socio-political changes, with special focus on their different typology; and ii) to assess, comparatively, the different managerial and gardening practices of the three types of gardens and their implications on collectivity, in order to identify if all of them challenge the same purposes in their gardening practices.

\section{Materials, methods and study area}


The City of València is located in eastern Spain, with around 800.000 inhabitants in its administrative area and around 1.5 million people including the urban area beyond these limits. The boundaries of the VMA are widely spread. We focus our study area in the urban continuum limited by the municipalities of Foios (North), Paterna and Torrent (West) and Silla (South), including 34 municipalities and 1.42 millions of inhabitants.

València has a Mediterranean climate (Köppen Csa) with hot and dry summers, which makes irrigation necessary to maintain urban agriculture. The city is surrounded by a large historical irrigation market garden (Horta de València), which has been partially occupied and severely fragmented by the urban sprawl throughout the $20^{\text {th }}$ Century. The expansive process accelerated during the period 1998-2008, due to the Spanish property boom. This caused the birth of a strong social movement vindicating the protection of the periurban historical irrigation system. Due to the 2008 speculative bubble bursting, urban agriculture blossomed in three types of areas: vacant plots resulted from the failure of building projects; public lands without use; and private properties (through rental contracts).

The research was developed in three phases. First, we performed an inventory and typology of the collective gardens of the VMA, to achieve a global understanding of this phenomenon. Second, we selected 7 community gardens, representative of the different typologies identified in the preliminary inventory, to develop in-depth interviews and field visits. Third, we conducted and analyzed interviews and field observations.

The inventory of the community gardens was developed by means of several techniques. We identified and mapped their locations through ArcGis 3.2 (ESRI, Redlands, California) using the 2015 ortophoto from the Spanish National Plan of Aerial Ortoimages (PNOA) and Google Maps. Subsequently, we obtained basic information about the origin and structure of these gardens through field visits, phone calls, and websites consultation. The inventory of municipal public gardens published by the provincial administration (DPV, 2013) was also useful in characterizing 7 of the gardens publicly managed. The inventory was made in the spring of 2015 and updated in the spring of 2018 (Figure 2).

We selected 2 rental gardens, 2 municipal gardens and 3 associative gardens for in-depth interviews, from the 48 inventoried. Table 1 summarizes the main characteristics of these gardens. Managers and users were interviewed during spring of 2015 which took place always in the garden setting and lasted an average of 60 minutes. A question guide was developed to introduce topics in the conversation although it was an open interview format. A total of 24 people, managers and gardeners (Table 2) took part, and field observations and transcriptions were used in the analysis. Three other people that had abandoned the collective gardens were also interviewed and asked their reasons for quitting.

\section{Results}

\subsection{Characteristics of the VMA community gardens}

We have identified 48 community gardens in the study area, 12 of which are held by NGOs and local associations, 11 are publicly managed, and 25 are renting gardens owned by 19 entrepreneurs or local farmers. Most of them were created in the last decade.

Associative community gardens 
Neighbors' associations, ecologist organizations, social or educational NGOs and local committees of political parties have launched a dozen of community gardens in the VMA since 2010. Most of them (9) have been located on building plots inside the compact urban area, after the failure of development projects, and 3 occupy land protected from urban developments in old agricultural areas. Some of them were directly created by associations linked to the 15-M movement while others were launched by agro-environmental associations or old neighbor associations. This effervescent creation of collective gardens shows the same characteristics to other Spanish cities as Alicante or Madrid (Simon-Rojo et al., 2018; Seguí et al., 2017)

These cases have been developed in the urban fringes where land tenure is uncertain. Part of them have achieved agreements with local administration or land owners, most of them banks, for land cession, while others have squatted abandoned plots to carry on their projects. Land tenure is a critical fact, because in some cases (in Valencian associative gardens and in other cities) occupation is the origin of the community garden, as a strategy to colonize urban interstices to re-green the city, and also to stop new urban developments. These territorial strategies were the main motivation for the CSOA L'Horta and other associative collective gardens of the northern area of the city (Neighbors' Association of Benimaclet), while other associations prioritized food sovereignty goals.

Water supply is also uncertain in several gardens. In some cases, informal agreements have been reached with the local traditional associations of water users for irrigation to regularly receive water, while one of the interviewed gardens depend on the irrigation return flows from other community garden to receive the necessary water input.

The governance of these associative gardens adopts different forms. Most of them rely directly on government boards to deal with the most important decisions of the garden, although these have to be verified afterwards in a general assembly. The board is made up of volunteers among the users. Furthermore, the community gardens founded by groups of activists involved in the 15-M movement work directly through a popular general assembly. These gardens promote many parallel activities, which take place in the site, but all of them have to be endorsed horizontally by the general assembly, because they do not have any government board.

"I've always believed in assemblies. I do not agree with a vote (...) In spaces like this you can create that, (...) you can get a consensus by assembly. But of course, you spend more time, you spend more work. (...) You also make sure that what is being chosen, is being chosen by all who participate in the assembly" (I-14)

These associative collective gardens show how the social capital which emerged during the crisis, in the form of the $15 \mathrm{M}$ movement or other agro-environmentalist organizations, is being spatially materialized and is contributing to reshape and green some urban tesserae, in line with other urban informal green guerrilla movements (Hardman et al., 2018). The main singularity in the VMA is that almost all of the cases assign individual plots for the users, combining collectivity and individuality with a focus on common goals and duties.

\section{Municipal community gardens}

Several city councils from the VMA have been implementing community gardens since 2003. Some of them are self-defined as leisure gardens and others as social gardens, depending on the target group. Plots are distributed through lotteries in municipal leisure gardens, but allocated by economic criteria in the case of the social ones. These criteria are also used in other cases in Southern European countries affected by the economic crisis of 2008, such as Greece, where 
unemployed people, large families or single-parent families received a bonus in the selection process to access the collective gardens (Partilidou et al., 2017)

The municipal gardens are managed by the city councils, which establish municipal rules as legal framework, and provide technical and managerial support for garden users, which involve opening gates, control payments, but not with agricultural activities. In most of them, in parallel to the city management, users have created an association, which is responsible for some internal administration practices and for the development of social activities. These associations are governed by a board of volunteers, although general assemblies take place regularly to make collective decisions. This procedure establishes a singular formula of public-private partnership, slightly different from the model of other countries, where the public role is oriented to support third-party community gardens, as the New York City's Green Thumb (Henderson and Hartsfield, 2010).

These gardens have been consolidated and further promoted due to the political changes that occurred in the local elections of 2015. Most of the municipal community gardens were created by city councils controlled by left-wing parties completely or partially aligned with the post-crisis $15 \mathrm{M}$ movement principles. The case of the València City Council is the only exception to this political trend. The municipal garden was launched by a conservative party after the failure of an urban development project (Sociopolis), designed to build a new suburb of skyscrapers attached to agricultural gardens for the new urban dwellers. When the construction of the buildings stopped due to the lack of buyers, the city council decided to launch a collective garden in these lands.

\section{Rental Community Gardens}

Rental community gardens have received little attention compared to other collective gardens. There are only few documented examples of individual plot rentals. In Switzerland and The Netherlands, Knapp et al. (2016) have identified entrepreneurial garden projects that, among other services, have small plots where customers could harvest their products directly. In Bonn, an external company offers a venture between professional farmers and citizens to cultivate individual plots (Hahn et al., 2018). Terada (2017) has analyzed a similar formula in Japan, where various external enterprises have begun to offer "rental farms" to urban citizens in order to increase farmers' incomes and maintain peri-urban farmland. In other cases, professionals, either technicians or farmers, are hired to manage the collective garden offering help and guidance to users (Fox-Kämper et al., 2018).

However, the private initiatives in València have singular characteristics. Some farmers and entrepreneurs owning lands in vacant building areas or close to the compact urban area have created rental gardens as a new entrepreneurship business, imitating the structure and organization of the public and associative collective gardens. They have divided their plots in small allotments (normally 25, 50 or $100 \mathrm{~m}^{2}$ ) that are rented to individuals, families or groups of friends, to whom they offer guidance and provide basic services. They offer the clients a welldesigned service package, and they normally take care of the most complicated tasks, such as operating the tractor and pest control, and also guide users in the simplest agricultural actions, such as planting or harvesting the crops. In some cases, they also sell their own organic farming products to users.

Two types of farmers run the rental gardens. Some of them are entrepreneurs that worked in the service or construction sectors before the crisis. They developed this business on their parents' lands after the bankruptcy of their own businesses or the loss of their jobs, as an 
alternative to re-organizing their life. The others were farmers before the crisis, which currently want to promote organic farming practices and principles. They decided to change their relationship with consumers as a way to survive the structural crisis of the agricultural sector in the region. This model of business provides them with their main source of income or a complement to other agricultural incomes.

The singularity of the Valencia rental gardens is based on two facts. On the one hand, farmers offer this service to the community without any intermediate or external company, favoring the communication between farmers and consumers with the goal of promoting local products and food sovereignty. On the other hand, the proportion of this phenomenon in this city is quantitatively much more relevant that in other countries.

The success of this formula is due to the fact that the increased demand for urban agriculture facilities has created long waiting lists (more than 254 people) in municipal and associative gardens in València City. The lack of available plots has stimulated the increase of the private offer of community gardens. This rental gardens started to appear in the north of València City after the financial crisis, due to a higher availability of land, better landscape quality and good transport connection by bicycle, all of which make this area highly appreciated for leisure. Subsequently, they have spread throughout the peri-urban area.

\subsection{Collectivity in the VMA community gardens}

In this section, collectivity is analyzed with a broad perspective in the three abovementioned types of gardens, combining three approaches. The analysis explores: i) the learning processes that take place in urban garden (because of their influence in community building); ii) common resources management, and iii) the social and political involvement of users and managers.

\section{Learning process: communities of practice}

Reception and support of new participants are essential for the correct functioning and coexistence in the garden. Each garden model has a different strategy to inform and to accompany the new users at the beginning of the learning process. Rental gardens have a detailed procedure: normally they show the garden in the first visit, during which they explain the basic rules and they recommend a 25,50 or $100 \mathrm{~m}^{2}$ plot, depending on the number of users, their vital objectives and their free time. In the second visit, they begin working on the field with some recommendations on what to grow and when. From this moment on, the user is free to begin cultivating at any time. Some of them forbid night working or leisure activities, while others allow it. The owner is available for consultation on the field within a particular timetable. Outside of this, answers to questions are carried out through social media networks. Fees are variable, depending on the location and services, although an average price varies between 25 and 50 euros per month for a $50 \mathrm{~m}^{2}$ plot.

However, for municipal and associative gardens, the procedure is more autonomous. First, they have to become members of the association and pay a membership fee, with a maximum of 50 euros per year. In addition, there are different ways to inform users of rules. All the municipal gardens and some of the associative ones have established statutes that explain how to participate in the garden, although some of these have been passed several years after the garden creation. Only the $15 \mathrm{M}$ movement gardens oblige users to participate in a general 
assembly before cultivating a plot. However, it is very common to rely on neighbor plot users or technicians to become familiar with the rules. Similar procedures and strategies are followed in other cases such as Stockholm (Bonow and Normark, 2017) or Rome (Mudu and Marini, 2018).

Agronomy is perceived as a challenge for the new users; most of the participants have no previous knowledge of agriculture, but they quickly develop new skills in gardening and agriculture.

"I started in September, and I did not even know how to make a furrow ... At first you're a little overwhelmed, then you begin little by little, and then you already improvise." (I14)

All surveyed gardens practice organic farming and some of them raise animals, mainly chickens and ducks. The main agricultural practices that they have to learn, either by attending seminars or by consulting the technicians, are pest control, crop rotation, composting or irrigation. Many of the solutions can be found on the internet or by recommendation from more experienced users. Sometimes people learn by trial and error, so that species which cannot grow together can be seen, while some users do not leave enough planting distance for the plants to grow correctly. However, according to the managers interviewed, it is common to see a dramatic evolution in the users after their second or third year in the garden. The permanent learning of the gardeners allows the improvement of their agricultural practices year after year (Cumbers et al., 2018).

The exchange of information among users and between users and technicians is determinant in this process. For this reason, communication is a key element in maintaining the learning processes and community life. Apart from the conversations between users on the ground or in the resting areas, communication strategies vary from a blackboard in the field where some warnings and news are shown, to a more online approach using social networks like Whatsapp (C) or Facebook (C). The participants of all the different types of gardens surveyed seem to be completely satisfied with their strategies and they valued positively the communication among managers, technicians and users.

In short, municipal, associative and rental gardens act as communities-of-practice, in terms of mutual learning of agro-environmental practices (Wenger, 2000 and Bendt et al, 2013). Interviews show how users share their experiences and techniques in a collective learning process, by talking, sending messages through social networks or merely observing. There is a permanent flow of information with a double dimension, between neighbors and from experienced users to new-comers.

"When a new user enters, he must be helped by the interest of the Community. Moreover, there is a return of this solidarity, because a new happy member has a clean and well-kept plot that will not lead to pests and contribute to the wellbeing of the garden." (I-13)

\section{Collective resources and tasks}

In associative and municipal gardens, collective tasks are required and carried out by the users in collaborative work. The first obligation is for each person to look after their own garden. This is the first collaborative task because of the pest infestation and growth of weed in the garden. Secondly, the users have to take care of the water channels and irrigation planning. Finally, the 
users have to take care of community services related to the garden organization, along with common spaces such as roads, picnic and rest areas.

Far from transmitting an idealistic view of the Valencian community gardens, interviews also show that these spaces are not immune to internal conflicts, as Teig et al (2009) have observed. However, they have been capable of developing mechanisms for resolving conflicts, such as public regulations or shareholders' resolutions as warnings or loss of right of cultivation in extreme situations. Conflicts appear when participants do not collaborate. Facing that situation, a clear set of rules help the success of collective gardens (Baker, 2004), such as in other forms of common-pool resources management. In the last five years, most of the municipalities managing collective gardens have passed regulations to create a legal framework to prevent and solve conflicts. In case of a reiterative breach of regulations in the Valencian associative and municipal gardens, the mechanism to control community collaboration is to expel the users and give the plot to someone else. This is a very conflictive issue and it is not easy to manage, although it happens quite frequently.

"Now, for example, there is an orchard above, which had been given an ultimatum, because the technician had already told them twice to fix it and they did not do it. Then he told them if they did not fix it by Monday they would be expelled, and the field is already set" (I-15)

However, in the end, most of the users and managers highlight the cooperation between users and the social atmosphere in the gardens, although participants are aware of the difficulties of an associative process and their implications.

"You have to go little by little, and take short steps and consolidate them, because if you take big steps, in the end, you go back." (I-7)

In rental gardens, users do not have communal tasks (assumed by the manager), but share tools, irrigation turns and co-operate to cope with infestations or weeds and to keep common areas in good conditions. Conflicts caused by collective duties are easily overcome due to the permanent presence of a technician, which coordinates most of the communitarian work. Managers feel that their model is more sustainable and resistant than the associative ones particularly because the collective tasks are not done by the users. They feel that this private management can provide the best qualities of the collective gardens, and at the same time reduces much of their disadvantages.

Some collective tasks, such as irrigation or composting, are particularly difficult for users not familiarized with these techniques. Despite composting being a recurrent element for the interviewees who find the idea of recycling in line with their environmental and political concerns, collective composting has not worked correctly and most of the experiences have failed and, right now, only individual compost bin seems to succeed. However, they positively valued the idea of exploring new collective composting projects and they would like to implement them for their organic residues. Experiences of composting in urban gardens are not often found in the literature, however they can be a good alternative to reduce waste disposal and reduce contamination (Egendorf et al., 2018). On the other hand, irrigation is not easy, mainly for non-expert users practicing surface irrigation. Turns have to be set up, and conflicts arise when irrigation has to be done at night or community gardens have to cooperate with the professional farmers that are using water from the same channel. 
In spite of these difficulties, managers and users positively value the interaction and cohabitation with neighbors in a day-to-day basis. The more direct relationship with other users is quite kind and they experience pleasant moments of interaction and mutual help.

"I am a volunteer of an association, and I think that coming here to a totally integrating and community site helps a lot. That is the most beneficial part for me more than my own garden" (I-14)

Moreover, in the three types of gardens spontaneous collaborative behaviors among neighbors have been observed, such as sharing surplus resources (straw to cover the soil or egg shells to dissuade snails) and products (some users give vegetables to neighbors when they have an excess of production or at the end of the season); sharing information and some advice on the effects of storms and infestations; and providing help to beginners with some specific agronomic tasks such as installing reeds for climbing plants.

\section{Social and political goals: the politics of collectivity}

The leisure activities are an essential part of the associative and municipal gardens, but also many rental gardens organize similar collective events --training talks on agro-ecology, festivals or popular lunches-- to strength social life. These events help to recruit new participants and to improve social relationship among users (similar to the Barcelona case explained by Langemeyer et al., 2018). According to the interviewees, rental gardens are also a good environment to socialize with neighbors and other gardeners.

"In the end you come to the orchard to enjoy it by yourself, but you also come a little bit for the environment in the garden (...) The children have become friends. When the school finishes in June, it seems a playground" (I-10)

Many activities are proposed in the gardens to increase their external visibility and the internal cohesion of the group. Users are proud of their effort and they feel a connection to nature and food growth, a common feeling in community gardens (Pollard et al., 2018; Kiesling \& Manning, 2010) that helps the relationship between the users and food and has implications on their health and wellbeing (Uhlmann et al., 2018). In addition, they are aware of the social implications of their actions and that their plots provide an environmental service to the city.

"They pass by our community garden and sometimes they tell us -This, instead of an orchard looks like a botanical garden. How beautiful you have it!-" (I-3)

Examples of benefits for community engagement are present in the literature. Activism in community gardens enables the participation of gardeners in other civil organizations and help to interact among neighbors (Atkinson et al., 2017). In the VMA case, many gardens also organize conferences, concerts or audiovisual festivals related to agricultural activities and the defense of the local territory, the agricultural landscape protection, and organic farming.

"Apart from working the land, it is important that we let people know (and that people know) that local producers exist, and that [this historical agricultural landscape] is a wealth that we have to preserve, because it is in process of extinction." (I-15)

Moreover, some of the gardens are involved in municipal or social initiatives to help local producers and promote and advertise local markets. Finally, the most politically involved gardens also participate in environmental and food sovereignty networks. Even, concerts, 
festivals or events are organized to raise money for alternative social movements focused on agro-ecology, ecofeminism or other political vindication proposed by Palestinian or Saharan collectives, among others. Some of the rental gardens do not avoid political issues such as food sovereignty vindication in their activities and their manifestos on their webpages or during the interviews. This political activism aligns VMA's community gardens with other Spanish initiatives (Fernández and Morán, 2015; Simon-Rojo et al., 2018; Langemeyer et al., 2018).

Rental gardens are not an exception. They also organize special lunches and festivals and places within the property to gather with neighbors and their families. This research shows that in the rental gardens analyzed one of the objectives of the promoters is for the society to become more aware of local agriculture and be more familiar with concepts such as agroecology or food sovereignty, similar to other initiatives such as local markets (Preiss et al., 2017), consumer's cooperatives (Moragues-Faus, 2017a) or farmer's direct selling (Pinna, 2017). These rental gardens do not seek only the economic benefit of the rental itself, but also better and healthier food and agricultural practices and environmental learnings (Marshall et al., 2017). Moreover, managers and numerous users also share a strong commitment of the defense and legal protection of the historical agricultural lands and green areas, participating and disseminating political actions in this direction (Figure 3). Engagement with societal vindications take place in a similar way as associative and municipal gardens do.

Hence, these gardens offer an opportunity to farmers to develop a business model which agrees with their values and also adapt to the needs and demands of the urban people who wants to evade from the day-to-day urban activities. Rental gardens are mostly managed by young farmers (<40 years), which do not want to follow the classical product commercialization, and leaned towards creating new opportunities by selling products directly to consumers in markets or shops or by offering other services, such as private collective gardens. This trend, although limited by the lack of generational shift in Spanish agriculture, is related to a new generation of farmers who explore new business model and are more sensitive to political and social movement, similar to what is described by Argüelles et al. (2018) in their general analysis of alternative direct market strategies. They also become more aware to the farmers' dignity and wellbeing and seek a competitive product in the market.

"In order to live as farmer today, you have to sell product with reasonable prices which people can afford, then you cannot go forward with one thing, you have to be producer and you have to offer also service activities, and you have to complement with different things" (I-9)

Because of this new professional orientation, they frequently "enjoy" agriculture instead "suffering it" (I-9), because of the positive feedback obtained from their new clients. Users appreciate these services and the help of these technicians in their plots.

"The crops go well because they explain everything, what you have to plant and do at each season" (I-11)

"Our services make users feel protected and supported in the adventure of gardening" (1-9)

Failed individual and collective projects 
Collectivity does not completely prevent from individual failures. Most of the farmers remain in the garden for many years, but there is a floating group of people that do not last long. The community gardens are becoming very popular and, as a result, many people want to participate, but sometimes users become overwhelmed by what it actually entails (Rogge et al., 2018). This causes a continuous turnover in participants:

"You see who likes the land, who has the satisfaction of watching the artichoke, the bean or the lettuce, and work at ease because they come at any time, and some others who come because of the novelty of the initiative and organic farming, and then realize that it requires some continuity and dedication to the land and they leave the project" (I-4)

According to the interviewees, three reasons explain this turnover: changes in personal conditions, lack of time to attend the agricultural requirements, and disenchantment after the first 1-2 years of experience. There is also some exceptional cases of people that, after acquiring experience and developing skills, quit the collective garden to rent a larger individual plot in the agricultural area surrounding the city (where smallholding is characteristic and they can practice crop-fallow rotations).

This research has also detected three cases of collective failure. Land tenure problems caused the failure of an associative garden with 7 years of successful experience (Solar Corona), which was pacifically dismantled and moved to other location when the owner of the land communicated to the users the start of the construction of a new building and a public garden. Another associative garden (Solar de la Botja) failed at its early stages because of the impossibility to obtain water for irrigation, and one rental garden project (Tavernes Blanques) was abandoned at the end of the first year due to insufficient number of clients. Other associative rental garden is currently at risk because of land tenure insecurity.

\section{Discussion and conclusions}

The Metropolitan Area of València is going through a post-crisis urban greening effect. The shock caused by the financial crisis and the real-estate bubble bursting has activated interests anesthetized by the previous economic prosperity. Urban greening trends and food sovereignty have been incorporated to the political anti-establishment discourses emerged during the worst period of the crisis, and social and environmentalist organizations and left-wing parties have acted as promoters of urban agriculture, implementing social or leisure collective gardens and protecting or supporting citizens' initiatives of vacant lands occupation. The increase of these projects in the Spanish Mediterranean coast after the crisis is reported also in the province of Alicante, south of València, where only 3 of 38 projects observed in 2014 were initiated before the 2008's crisis (Seguí et al., 2017). In the Valencian case, quantitatively, the urban greening effect is evident: 45 of the 48 collective gardens were created after the beginning of the crisis, and the vast majority of them are committed to food sovereignty and social or community building goals. The case of the VMA shows, as it happened in other countries and historical periods, how community gardens frequently appear or expand as a response to the recurring cycles of capitalism restructuring (Pudup, 2008). Nevertheless, we have to consider that urban agriculture has also expanded during the last decade in countries not so severely affected by the global financial crisis of 2008, such as The Netherlands or Switzerland (Knapp et al., 2016). For this reason, it is important to identify to what extent this expansion is part of a global phenomenon or has been influenced by the crisis itself.
Con formato: Color de fuente: Automático 
Beyond the quantitative parallelism, other evidences show that the crisis has acted as a catalyst, although the bases for this rapid growth of collective gardens were previously established, because organic farming and food sovereignty movements were already present and active in the country, and urban agriculture had older (but individual) forms. Four facts demonstrate the cathartic effect that the financial (and subsequently social and political) crisis have had on urban agriculture in Valencia. First, lands for urban gardening were not easily available before the crisis, because the urban area expanded very quickly over the agrarian lands. The speculative bubble bursting stopped the transformation of the cultivated areas and "released" unconsolidated urban land (owned by banks or ruined construction companies) which paved the way to new informal land uses, such as urban gardens. Second, agriculture became a "refuge sector" for unemployed workers or ruined entrepreneurs, some of which opted for the creation of rental gardens on their family lands. Third, both the social and political organizations born in the heat of the $15 \mathrm{M}$ movement and the old neighbors' associations played a critical role in urban greening struggles or vindications, avoiding the development of constructing projects or mobilizing users against new infrastructures or in favor of the protection of the historical irrigation system. This is the origin of 5 of the associative gardens of the VMA. These communitarian projects represent a scalar strategy to re-appropriate the urban space, which is taking place in other European cities (Mudu and Marini, 2018) and revive the old forms of the urban green guerrilla (Hardman et al., 2018). Fourth, these movements began to build momentum in proposing public policies when they started to participate in the left-wing political alliances governing in several municipalities, particularly after May 2015. In the VMA, 10 of 11 municipal gardens were launched by these political organizations.

Therefore, since 2008, urban agriculture has migrated in the VMA, such as in other Spanish cities, from individual opportunistic forms, widely generalized in the second half of the $20^{\text {th }}$ century, to collectively managed gardens, mainly developed after the financial crisis with different levels of public support. This process is similar to what Slavuj et al. (2016) have observed in Croatia, distinguishing between old -with no organized management-- and new garden models, collectively or publically managed. Setting aside the different organizational structure, in both Mediterranean countries these spaces show a contrast between a model of marginal socionature products, because of the rural exodus and late industrial development, and a postindustrial model manifestation of rebellious perspectives, which build alternative spaces of consumerism and standardized production formulae. This mutation belatedly align the Spanish urban agriculture, and probably the whole Euro-Mediterranean region, with other world urban scenarios where the green activism practices have been created (Hardman et al., 2018).

Collectivity is the defining feature of this transformation. In the VMA gardens, collectivity is achieved by different ways. First, these gardens behave as communities of practice (Bendt et al. 2013; Wenger, 2000), where individual and collective learning are mutually interacting, facilitating both the consolidation of the garden projects and the achievement of the individual goals. Second, the current collective garden models follow common-pool management strategies and procedures, such as other European gardens (Rogge and Theesfeld, 2018). These spaces are conceived to promote relationships among users with common areas, common duties and garden activities agreeing with the collectivity definition by Exner and Schützenberger (2018). And last but not least, the community gardens also pursue processes of change with "politics of collectivity" (Moragues-Faus, 2017a) related to food sovereignty or agricultural landscape protection. 
Collectivity goals are sometimes not explicit, but we have observed, among farmers/technicians and users, social and cohesive communitarian practices, in either rental, associative or municipal models. In the VMA case, these practices vary from common responsibilities to normative restrictions, also defined as strategic for group cohesion (Egerer and Fairbairn, 2018). However, in the three types of community gardens we have documented users that have only individualistic goals, and do not contribute to community building processes. The degree of involvement in the collective objectives is, in the end, an individual decision, not strictly connected to the garden type.

This research has observed collectivity in three types of gardens in the three dimensions discussed previously as it summarized in table 3 . It is important to highlight the political involvement of all types of gardens, including rental ones, in the promotion of food sovereignty, direct selling or local markets. With regard to the models of community gardens observed in other countries, the case of València is peculiar, because of the importance of the rental gardens. These garden projects are the consequence of the convergence of the enormous demand from citizens to regain contact with food production, and the entrepreneurship come up as a way out of the economic crisis. The success of this innovative garden type suggests the possibility of exporting or adapting this formula to other urban areas with active periurban agriculture, in order to interconnect local traditional farmers with urban dwellers, obtaining mutual benefits.

This specific garden form probably does not completely fulfill the academic definitions of community garden, such as the approaches performed by Guitart et al. (2012) or Bendt et al. (2013), which seem to exclude those spaces not strictly collectively managed. However, these gardens are a clear expression of projects "animated by an ethos of individual responsibility" that characterizes the notion of organized garden projects elaborated by Pudup (2008). Beyond the academic formulation, in terms of collectivity the analysis of the Valencian rental gardens shows frequent coincidences with the collectively managed community gardens. They are not conceived as a mere business by their managers. Most of them participate actively in alternative food networks. The aims of both managers and users/clients, are goals of food sovereignty and organic farming, and reflect a will of overcoming the metabolic rift (McClintock, 2010) between urban dwellers and the agricultural practice.

The boundaries between the different types of gardens frequently become diffused when collectivity or managerial aspects are analyzed. We have seen municipal gardens whose management is led by an association of users, while others, despite having their own association, are more dependent from the city council technicians. In these cases, the relationship between the technician and the users is similar to the managerial practices observed in rental gardens. Moreover, in associative community gardens, depending on the aims and the structure of the organization (political-oriented, educational, neighbors' association) the community garden is managed with different nuances.

In conclusion, the co-existence of these three different models (rental, associative and municipal) must be positively assessed, because there is certain complementarity of their aims and values, and also of the public and private roles. Entrepreneurial initiatives (rental or associative gardens) endorse the majority of the collective gardens, proves the strength of the post-crisis greening phenomena and probably guarantees the sustainability of this reshaping of the urban interstices. However, public policies are the decisive factor in consolidating these processes, in València and other cities. With regard to the municipal gardens, when there is a growing demand and a wide offer of rental or associative gardens, the public effort should be 
mainly oriented to social aims, prioritizing income, education and social inclusion as preferential criteria for plots allocation. Public involvement is also required by those gardens with land tenure or water supply insecurity, to consolidate their local spatial acquisitions, as a part of wider re-greening post-crisis strategies.

\section{Acknowledgements}

Authors thank the managers and users of the VMA collective gardens for their time and helpfulness, and also for their contribution to improve the metabolism of the VMA. We also thank the anonymous reviewers for their suggestions, which substantially improved the paper.

\section{References}

Agustina, I., \& Beilin, R. (2012). Investigating Migrants Adaptation Process through Gardening Practices in Community Gardens. Asian Journal of Environment-Behaviour Studies, 3(6), 121130.

Armstrong, D. (2000). A survey of community gardens in upstate New York: implications for health promotion and community development. Health and Place 6, 319-327.

Atkinson, A.E., Hutchison, P., Reischl, T.M., \& Alaimo, K. (2017). We don't only grow vegetables, we grow values: Neighborhood Benefits of Community Gardens in Flint, Michigan. In Community Research in Environmental Health (pp. 137-156). Routledge.

Aubry, C., Ramamonjisoa, J., Dabat, M.H., Rakotoarisoa, J., Rakotondraibe, J., \& Rabeharisoa, L. (2012). Urban agriculture and land use in cities: an approach with the multi-functionality and sustainability concepts in the case of Antananarivo (Madagascar). Land Use Policy, 29(2), 429439.

Baker, L.E. (2004). Tending cultural landscapes and food citizenship in Toronto's commnunity gardens. Geographical Review, 94 (3), 305-325.

Ballesteros, G. (2014, March). Iniciativas de Agricultura Urbana y Periurbana Ecológica en España. II Congreso Estatal de Agricultura Urbana y Periurbana Huertos Urbanos, autoconsumo y participación social, Sevilla (Spain).

Barthel, S., Folke, C., \& Colding, J. (2010) Social-ecological memory in gardening: Retaining the capacity for management of ecosystem services. Global Environmental Change 20, 255-265.

Beck, U. (1992). Risk society: Towards a new modernity (Vol. 17). Sage.

Bendt, P., Barthel, S., \& Colding, J. (2013). Civic greening and environmental learning in publicaccess community gardens in Berlin. Landscape and Urban Planning 109 (1): 18-30

Bonow, M., \& Normark, M. (2018). Community gardening in Stockholm: participation, driving forces and the role of the municipality. Renewable Agriculture and Food Systems, 1-13.

Cabral, I., Keim, J., Engelmann, R., Kraemer, R., Siebert, J., \& Bonn, A. (2017). Ecosystem services of allotment and community gardens: A Leizpig, Germany case stud., Urban Forestry and Urban Greening, 23, 44-53. 
Corrigan, M.P. (2011). Growing what you eat: developing community gardens in Baltimore, Maryland. Applied Geography 31, 1232-1241.

Cumbers, A., Shaw, D., Crossan, J., \& McMaster, R. (2018). The work of community gardens: Reclaiming place for community in the City. Work, employment and society, 32(1), 133-149.

DPV. Huertos urbanos y periurbanos en la provincia de València, Servicio de Medio Ambiente, Diputació Provincial de València (2013). http://www.dival.es/sites/default/files/medioambiente/Estudio1.pdf Accessed 9 December 2018

Domene, E., \& Saurí, D. (2007). Urbanization and class-produced natures: vegetable gardens in the Barcelona Metropolitan Region. Geoforum 38, 287-298.

Drake, L., \& Lawson, L.J. (2014). Validating verdancy o vacancy? The relationship of community gardens and vacant lands in the US. Cities, 40, 133-142.

Egendorf, S. P., Cheng, Z., Deeb, M., Flores, V., Paltseva, A., Walsh, D., Groffman P. \& Mielke, H. W. (2018). Constructed soils for mitigating lead $(\mathrm{Pb})$ exposure and promoting urban community gardening: The New York City Clean Soil Bank pilot study. Landscape and Urban Planning, 175, 184-194.

Egerer, M., \& Fairbairn, M. (2018). Gated gardens: Effects of urbanization on community formation and commons management in community gardens. Geoforum, 96, 61-69.

Egerer, M. H., Philpott, S. M., Liere, H., Jha, S., Bichier, P., \& Lin, B. B. (2018). People or place? Neighborhood opportunity influences community garden soil properties and soil-based ecosystem services. International Journal of Biodiversity Science, Ecosystem Services \& Management, 14(1), 32-44.

Exner, A., \& Schützenberger, I. (2018). Creative Natures. Community gardening, social class and city development in Vienna. Geoforum, 92, 181-195.

Faus, P. 2012. La ciudad jubilada. The retired city. MACBA, Barcelona. https://issuu.com/paufaus/docs/laciudadjubilada Accessed 9 December 2018

Fernández de Casadevante, J.L., \& Morán, N. (2012). Nos plantamos! Urbanismo participativo y agricultura urbana en los huertos comunitarios de Madrid. Hábitat y Sociedad, 4, 55-71.

Fernández de Casadevante, J.L., \& Morán, N. (2015). Raíces en el asfalto. Presente, pasado y futuro de la agricultura urbana. Madrid: Libros en Acción.

Filkobski, I. Rofè, Y., \& Tal, A. (2016). Community gardens in Israel: Characteristics and perceived function. Urban forestry and Urban Greening, 17, 148-157.

Fox-Kämper, R., Wesener, A., Münderlein, D., Sondermann, M., McWilliam, W., \& Kirk, N. (2018). Urban community gardens: An evaluation of governance approaches and related enablers and barriers at different development stages. Landscape and Urban Planning, 170, 59-68.

Giddens, A., \& Pierson, C., (1998). Making Sense of Modernity: Conversations with Anthony Giddens, Stanford University Press.

Glover, T.D. (2004). Social capital in the lived experiences of community gardens. Leisure Sciences, 26, 143-162. 
Guitart, D., Pickering, C., \& Byrne, J. (2012). Past results and future directions in urban community gardens research. Urban Forestry and Urban Greening 11(4), 364-373.

Hahn, R., Spieth, P., \& Ince, I. (2018). Business model design in sustainable entrepreneurship: Illuminating the commercial logic of hybrid businesses. Journal of Cleaner Production, 176, 439451.

Hale, J., Knapp, C., Bardwell, L., Buchenau, M., Marshall, J., Sancar, F., \& Litt, J.S. (2011). Connecting food environments and health through the relational nature of aesthetics: gaining insight through the community gardening experience. Social Science \& Medicine 72, 1853-1863.

Hardman, M., Chipungu, L., Magidimisha, H., Larkham, P. J., Scott, A. J., \& Armitage, R. P. (2018). Guerrilla gardening and green activism: Rethinking the informal urban growing movement. Landscape and Urban Planning, 170, 6-14.

Henderson, B. R., \& Hartsfield, K. (2009). Is getting into the community garden business a good way to engage citizens in local government?. National Civic Review, 98(4), 12-17.

Hodkinson, S.N. (2012). The new urban enclosures. City: Analysis of Urban Trends, Culture, Theory Policy, Action, 16: 500-518.

Holland, L. (2004). Diversity and connections in community gardens: a contribution to local sustainability. Local Environment 9, 285-305.

Jackson, T. (2009). Prosperity Without Growth: Economics for a Finite Planet. London, Earthscan.

Juan, J. (2015). Bones pràctiques en la gestió d'horts urbans col-lectius [Good practices for urban community gardens management], Bachelor Degree Thesis, Universitat Politècnica de València.

Kiesling, F.M., \& Manning, C.M. (2010) How green is your thumb? Environmental gardening identity and ecological gardening practices. J. Environ. Psychol. 30, 315-327.

Kingsley, J., \& Townsend, M. (2006). 'Dig in' to social capital: community gardens as mechanisms for growing urban social connectedness. Urban Policy \& Research 24, 525-537.

Kingsley, J., Townsend, M., \& Henderson-Wilson, C. (2009). Cultivating health and wellbeing: members' perceptions of the health benefits of a Port Melbourne community garden. Leisure Studies 28, 207-219.

Knapp, L., Veen, E., Renting, H., Wiskerke, J. S., \& Groot, J. C. (2016). Vulnerability Analysis of Urban Agriculture Projects: A Case Study of Community and Entrepreneurial Gardens in the Netherlands and Switzerland. Urban Agriculture \& Regional Food Systems, 1(1).

Langemeyer, J., Camps-Calvet, M., Calvet-Mir, L., Barthel, S., \& Gómez-Baggethun, E. (2018). Stewardship of urban ecosystem services: understanding the value(s) of urban gardens in Barcelona. Landscape and Urban Planning, 170, 79-89.

Madaleno, I. (2000). Urban agriculture in Belém, Brazil. Cities, 17 (1), 73-77.

Marshall, J., Price, M., England, J., LeGrand, K., \& Kirby, R. S. (2017). Engaging Florida Residents: Motivations and Impacts of Community Gardens in Tampa Bay. Journal of Community engagement and Scholarship, 10 (1): 130-140.

Maxwell, D., Levin, C., \& Csete, J. (1998). Does urban agriculture help prevent malnutrition? Evidence from Kampala. Food Policy, 23 (5), 411-424. 
McClintock, N. (2010). Why farm the city? Theorizing urban agriculture through a lens of metabolic rift. Camb. J. Reg. Econ. Soc. 3(2), 191-207

McClintock, N., \& Simpson, M. (2014). A survey of urban agriculture organizations and businesses in the US and Canada: Preliminary results. http://web.pdx.edu/ ncm3/files/PSU UA Survey.pdf, Last access july 2018

Milan Urban Food Policy Pact, (2015). http://www.milanurbanfoodpolicypact.org/, Last access July 2018.

Mongeot, L.J.A. (2000). Urban agriculture: definition, presence, potentials and risks. In N. Bakker, M. Dubbeling. S. Guendel, U. Sabel Kosehelda \& H. de Zeeuw, eds. 2000. Growing cities, growing food, urban agriculture on the policy agenda, pp $1-42$. DSE, Feldafing

Moragues-Faus, A. (2017a). Emancipatory or neoliberal food politics? Exploring the "politics of collectivity" of buying groups in the search for egalitarian food democracies. Antipode, 49(2), 455-476.

Moragues Faus, A. (2017b). Urban food policy alliances as paths to food sovereignty- Insights from sustainable food cities in the UK. In: Desmarais, Annette Aurelie, Claeys, Priscilla and Trauger, Amy eds. Public Policies for Food Sovereignty: Social Movements and the State., Routledge Studies in Food, Society and the Environment, London and New York: Routledge, pp. 147-163.

Morgan, K. (2009) Feeding the city: the challenge of urban food planning. International planning studies, 14 (4), 341-348

Mougeot, L.J.A, ed., 2005. AGROPOLIS. The social, political and environmental dimensions of urban agriculture. London, Earthscan.

Mudu, P., \& Marini, A. (2018). Radical urban horticulture for food autonomy: Beyond the community gardens experience. Antipode, 50(2), 549-573.

Nemore, C. 1998. Rooted in Community: Community Gardens in New York City, City Farmer: Canada's Office of Urban Agriculture, <http://www.cityfarmer.org/NYcomgardens.html \#NYCG>, Last accessed July 2018.

Nette, C. 2014. Community gardens as social action, Ashgate Publishing.

Patel, R. (2009) Food sovereignty. The Journal of Peasant Studies, 36 (3), 663-706.

Partalidou, M., \& Anthopoulou, T. (2017). Urban allotment gardens during precarious times: from motives to lived experiences. Sociologia ruralis, 57(2), 211-228.

Pinna, S. (2017). Alternative farming and collective goals: Towards a powerful relationships for future food policies. Land Use Policy, 61, 339-352.

Pirro, C., \& Anguelovski, I. (2017). Farming the urban fringes of Barcelona: Competing visions of nature and the contestation of a partial sustainability fix. Geoforum, 82, 53-65.

Pollard, G., Roetman, P., Ward, J., Chiera, B., \& Mantzioris, E. (2018) Beyond Productivity: Considering the Health, Social Value and Happiness of Home and Community Food Gardens. Urban Science, 2(4), 97. doi:10.3390/urbansci2040097 
Preiss, P., Charão-Marques, F., \& Wiskerke, J. S. (2017). Fostering Sustainable Urban-Rural Linkages through Local Food Supply: A Transnational Analysis of Collaborative Food Alliances. Sustainability, 9(7), 1155.

Pudup, M. (2008). It takes a garden: cultivating citizen-subjects in organized garden projects. Geoforum 39, 1228-1240.

Puente Asuero, R. 2016. Los huertos urbanos comunitarios en Andalucía. Conceptualización, identificación y claves para su gestión, PhD Thesis, Universidad de Sevilla.

Rogge, N., \& Theesfeld, I. (2018). Categorizing urban commons: Community gardens in the Rhine-Ruhr agglomeration, Germany. International Journal of the Commons, 12(2), 251-274.

Rogge, N., Theesfeld, I., \& Strassner, C. (2018). Social Sustainability through Social InteractionA National Survey on Community Gardens in Germany. Sustainability, 10(4), 1085.

Seguí, A. E., Maćkiewicz, B., \& Rosol, M. (2017). From Leisure to Necessity: Urban Allotments in Alicante Province, Spain in Times of Crisis. ACME: An International E-Journal for Critical Geographies, 16(2).

Shinew, K.J., Glover, T.D., \& Parry, D.C. (2004). Leisure spaces as potential sites for interracial integration: Community gardens in urban areas. Journal of Leisure Research, 36(3), 336-55.

Simon-Rojo, M., Bernardos, I. M., \& Landaluze, J. S. (2018). Food Movements Oscillating Between Autonomy and Co-Production of Public Policies in the City of Madrid. Nature and Culture, 13(1), 47-68.

Slavuj Borčić, L., Cvitanović, M., \& Lukić, A. (2016). Cultivating alternative spaces - Zagreb’s community gardens in transition: From socialist to post-socialist perspective. Geoforum, 77: 5160.

Smith, C. M., \& Kurtz, H. E. (2003). Community gardens and politics of scale in New York City. Geographical Review, 93(2), 193-212.

Swyngedouw E (2011) Interrogating post-democratization: Reclaiming egalitarian political spaces. Political Geography 30(7):370-380

Teig, E., Amulya, J., Bardwell, L., Buchenau, M., Marshall, J., \& Jill, S. (2009). Collective efficacy in Denver, Colorado: strengthening neighborhoods and health through community gardens. Health \& Place, 15, 1115-1122.

Terada, T. (2017). Urban Periphery Planning: Concept to Link Urban and Rural Communities in the 21st Century. In Labor Forces and Landscape Management (pp. 381-390). Springer, Singapore.

Tornaghi, C. (2014). Critical geography of urban agriculture, Progress in Human Geography, 38(4) 551-567

Uhlmann, K., Lin, B., \& Ross, H. (2018). Who Cares? The Importance of Emotional Connections with Nature to Ensure Food Security and Wellbeing in Cities. Sustainability, 10(6), 1844.

Viljoen, A. (2005). Continuous Productive Urban Landscapes: Designing Urban Agriculture for Sustainable Cities, Oxford, Elsevier 
Wang, H., Qiu, F., \& Swallow, B. (2014). Can community gardens and farmers' markets relieve food desert problems? A study of Edmonton, Canada. Applied Geography, 55, 127-137.

Wenger, E. (1998). Communities of Practice: Learning, Meaning, and Identity. Cambridge: Cambridge University Press.

Wenger, E. (2000). Communities of practice and social learning systems. Organization, 7(2), 225.

Zezza, A., \& Tasciotti, L. (2010). Urban agriculture, poverty, and food security: Empirical evidence from a sample of developing countries. Food Policy 35: 265-273.

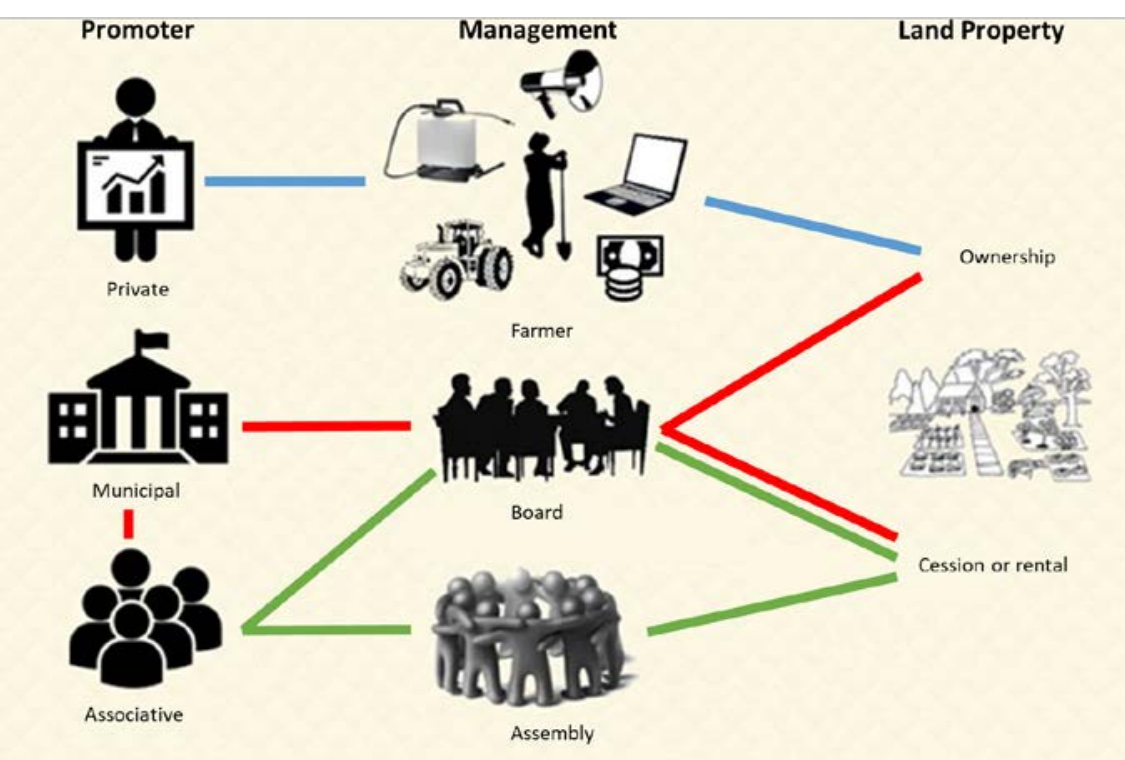

Figure 1. Management of collective gardens in València. Blue, red and green lines represent the different managerial options for the Valencian private, municipal and associative collective gardens, respectively. 


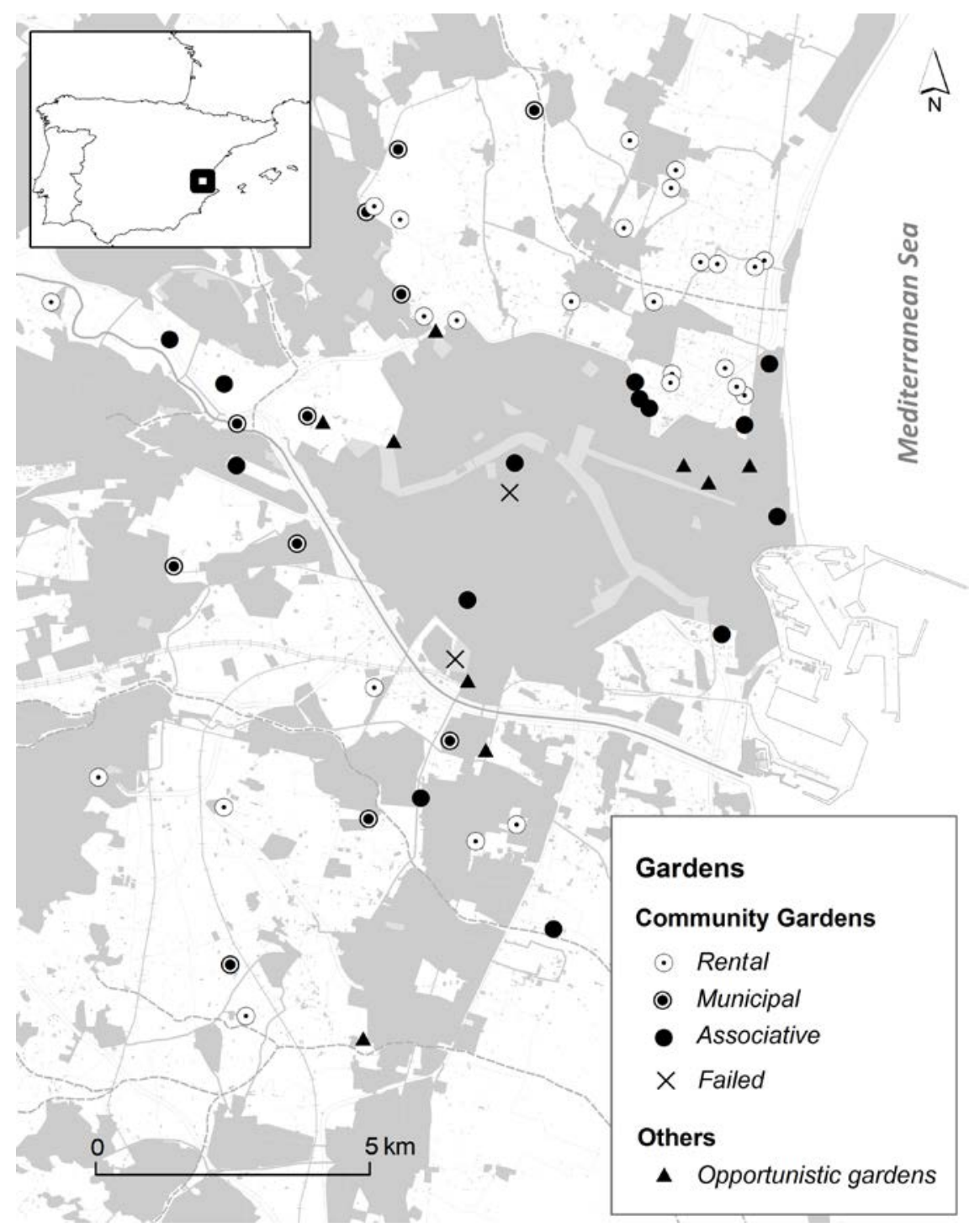

Figure 2. Location of the community gardens inventoried in the VMA, including failed and opportunistic gardens. 


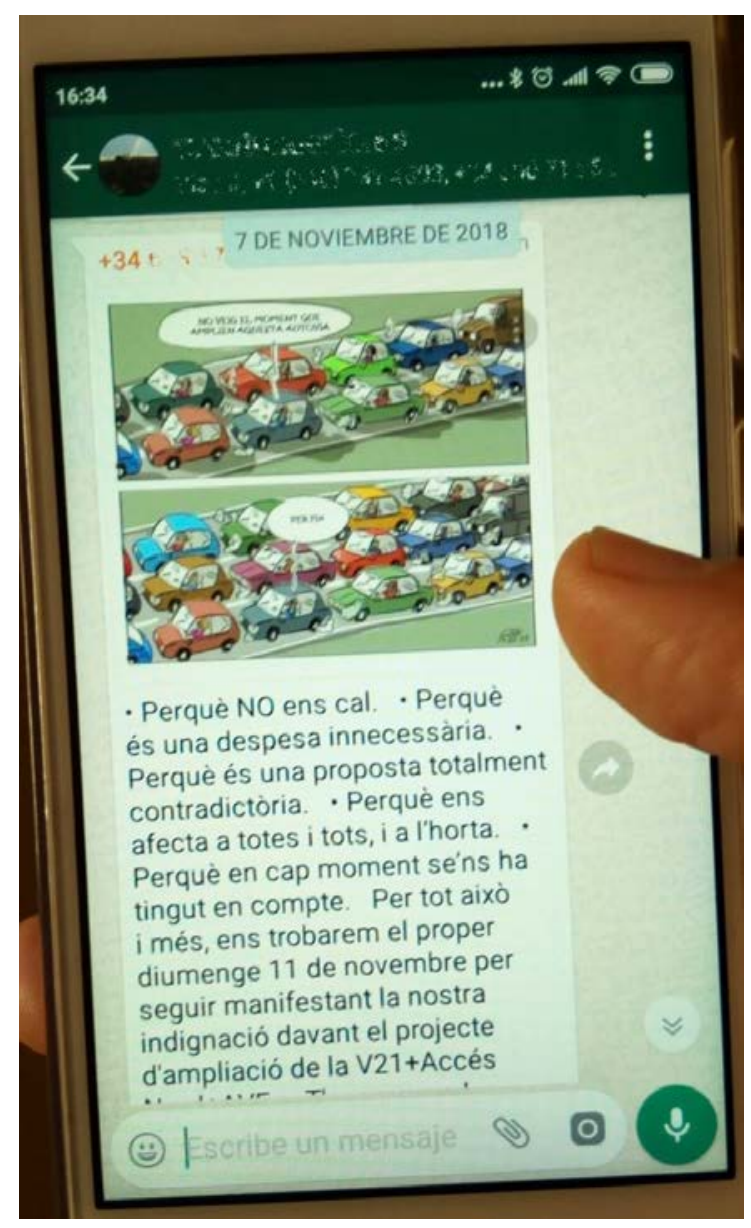

Figure 3. Message shared through a rental garden Whatsapp@ group, in order to mobilize users of the rental garden to participate in a demonstration to stop a motorway widening project, in order to preserve part of the historical agricultural area of the city. The same advertisement was published at least in two Facebook@ sites of associative collective gardens. The comic strip says: above "I can't see the moment they widen the motorway" below "It's about time!" The text of the call says: "Because we DON'T need it. Because it's an unnecessary investment. Because it's a contradictory proposal. Because it affects we all, and affects the Horta [historical agricultural area]. Because they have never considered us. For all these reasons, we will meet next Sunday $11^{\text {th }}$ November to demonstrate our indignation against the project of widening the V21 motorway..." 
Table 1. Characteristics of the selected community gardens

\begin{tabular}{|c|c|c|c|c|c|c|}
\hline Collective Garden & Promoter & Management & $\begin{array}{l}\text { Annual cost } \\
\text { perplot }(€)\end{array}$ & $\begin{array}{l}\text { Cultivated } \\
\text { Area } \\
\text { (ha) }\end{array}$ & $\begin{array}{l}\text { Number } \\
\text { of plots }\end{array}$ & Infrastructures \\
\hline Bicihuertos & Farmer & Technician & $420\left(50 \mathrm{~m}^{2}\right)$ & 0.30 & 60 & $\begin{array}{l}\text { WC, water, irrigation, } \\
\text { picnic and rest areas }\end{array}$ \\
\hline Agrolife & Farmer & Technician & $420\left(75 \mathrm{~m}^{2}\right)$ & 0.65 & 85 & $\begin{array}{l}\text { WC, water, irrigation, } \\
\text { picnic and rest areas }\end{array}$ \\
\hline CSOA L'Horta & NGO & Assembly & Free & 0.46 & 100 & $\begin{array}{l}\text { WC, water, irrigation, } \\
\text { picnic and rest areas }\end{array}$ \\
\hline L'Animeta & NGO & Board & $\begin{array}{l}10 \\
\text { (membershi } \\
\text { p fee) }\end{array}$ & 0.25 & 60 & $\begin{array}{l}\text { Irrigation, picnic and } \\
\text { rest areas }\end{array}$ \\
\hline CEM Julia & NGO & Board & Free & 0.13 & 10 & $\begin{array}{l}\text { Irrigation, picnic and } \\
\text { rest areas }\end{array}$ \\
\hline $\begin{array}{l}\text { Godella Leisure } \\
\text { Municipal Garden }\end{array}$ & $\begin{array}{l}\text { City } \\
\text { council }\end{array}$ & Board & $\begin{array}{l}50 \\
\text { (membershi } \\
\mathrm{p} \text { fee) }\end{array}$ & 1.25 & 150 & $\begin{array}{l}\text { Irrigation, picnic and } \\
\text { rest areas }\end{array}$ \\
\hline $\begin{array}{l}\text { Burjassot Social } \\
\text { Municipal Garden }\end{array}$ & $\begin{array}{l}\text { City } \\
\text { council }\end{array}$ & $\begin{array}{l}\text { Board }+ \\
\text { technician }\end{array}$ & $\begin{array}{l}30 \\
\text { (membershi } \\
\text { p fee) }\end{array}$ & 0.75 & 94 & $\begin{array}{l}\text { Water, irrigation, } \\
\text { picnic and rest areas }\end{array}$ \\
\hline
\end{tabular}

Table 2. Interview code for citations, sex, role and garden of the interviewees.

$\begin{array}{lll}\text { Code } & \text { Interviewees } & \text { Garden } \\ 1 & \text { Male manager } & \text { Bicihuertos } \\ 2 & \text { Female gardener } & \text { Bicihuertos } \\ 3 & \text { Male gardener/manager } & \text { CEM Julia } \\ 4 & \text { Female gardener/manager } & \text { CEM Julia } \\ 5 & \text { Male gardener/manager } & \text { CEM Julia } \\ 6 & \text { Male gardener/manager } & \text { CEM Julia } \\ 7 & \text { Female manager } & \text { L'Animeta } \\ 8 & \text { Male gardener } & \text { L'Animeta } \\ 9 & \text { Female manager } & \text { Agrolife } \\ 10 & \text { Male gardener } & \text { Agrolife } \\ 11 & \text { Female gardener } & \text { Agrolife } \\ 12 & \text { Male gardener } & \text { CSOA L'Horta } \\ 13 & \text { Male gardener } & \text { CSOA L'Horta } \\ 14 & \text { Female gardener } & \text { CSOA L'Horta } \\ 15 & \text { Female manager } & \text { Godella LMG } \\ 16 & \text { Male gardener } & \text { Godella LMG } \\ 17 & \text { Male manager } & \text { Godella LMG } \\ 18 & \text { Male gardener } & \text { Godella LMG } \\ 19 & \text { Male gardener } & \text { Burjassot LMG } \\ 20 & \text { Male gardener } & \text { Burjassot LMG } \\ 21 & \text { Female technician } & \text { Burjassot LMG } \\ 22 & \text { Female gardener/manager } & \text { Burjassot LMG } \\ 23 & \text { Male gardener/manager } & \text { Burjassot LMG } \\ 24 & \text { Male gardener/manager } & \text { Burjassot LMG } \\ 25 & \text { Female gardener } & \text { Quit } \\ 26 & \text { Male gardener } & \text { Quit } \\ 27 & \text { Female gardener } & \text { Quit } \\ & & \end{array}$


Table 3. Collectivity in the three type of gardens defined at VMA

\begin{tabular}{|c|c|c|c|}
\hline Garden & Learning processes & Resources management & Political attitudes \\
\hline Associative & $\begin{array}{l}\text { Most of the gardens have } \\
\text { statutes and some of them } \\
\text { oblige the gardeners to } \\
\text { participate in the general } \\
\text { assembly prior to become a } \\
\text { member. }\end{array}$ & $\begin{array}{l}\text { Tasks are carried out by } \\
\text { users in collaborative work } \\
\text { for both their own plot and } \\
\text { general duties. }\end{array}$ & $\begin{array}{l}\text { Dissemination events, leisure } \\
\text { activities, and participation of } \\
\text { food sovereignty networks } \\
\text { and political vindication. }\end{array}$ \\
\hline Municipal & $\begin{array}{l}\text { Statutes explaining how to } \\
\text { participate in the garden. A } \\
\text { more autonomous process } \\
\text { during the learning period. }\end{array}$ & $\begin{array}{l}\text { Similar to associative } \\
\text { gardens, except the } \\
\text { presence in some cases of } \\
\text { municipal technicians. }\end{array}$ & $\begin{array}{l}\text { Dissemination events, leisure } \\
\text { activities and relation with } \\
\text { municipal initiatives as local } \\
\text { markets. }\end{array}$ \\
\hline Rental & $\begin{array}{l}\text { Detailed procedure with an } \\
\text { organized first visit and a } \\
\text { personal coaching by a } \\
\text { farmer or a technician. }\end{array}$ & $\begin{array}{l}\text { Users are not obliged to } \\
\text { carry out communal tasks, } \\
\text { however they share tool-s } \\
\text { and common spaces. }\end{array}$ & $\begin{array}{l}\text { Dissemination events, leisure } \\
\text { activities and promotion of } \\
\text { farmers' direct selling and } \\
\text { local markets. }\end{array}$ \\
\hline
\end{tabular}

